\title{
Effects of Plant Media And Fertilization on The Growth of Orchid Plant (Dendrobium sylvanum rchb. F.) in Acclimatization Phase
}

\author{
DOI: 10.18196/pt.2019.095.66-72
}

\author{
Sucipto Hariyanto*, Ahmad Ridlwan Jamil, Hery Purnobasuki \\ Department of Biology, Faculty of Science and Technology, Airlangga University, \\ Campus C Unair, Jl. Dr. Ir. Soekarno, Surabaya 60115, Indonesia \\ *Corresponding author, email: sucipto-h@fst.unair.ac.id
}

\begin{abstract}
This study was to evaluate the effect of plant media variation, time of fertilization, and combination of both on the growth of orchid plant Dendrobium sylvanum Rchb. $f$. in acclimatization phase. This study was designed using $6 \times 4$ factorial experimentation. The first factor was the variation of plant media: charcoals, coconut husk, bagasse, mixing of charcoal and coconut husk, combination of charcoal and bagasse, combination of coconut husk and bagasse. The second factor was fertilization time: no fertilization, 7 day-fertilization, 14 day-fertilization, and 20 day-fertilization for three months. The data were analysed by using Two Way MANOVA ( $\alpha=5 \%$ ) and Duncan test. Based on the results, there were differences between media variation and fertilization time on the increase of leaf length and width, stem diameter, and root length of Dendrobium orchid in acclimatization phase. Combination of bagasse and coconut husk media showed the best result on media treatment. The best of fertilization time was 14 days. Moreover, the best of interaction between media and fertilization time showed by the combination of bagasse and coconut husk with 14 days-fertilization.

Keywords: Growing media, Fertilization, Growth, Dendrobium
\end{abstract}

\section{ABSTRAK}

Penelitian ini bertujuan untuk mengetahui pengaruh variasi media tanam, waktu pemupukan dan kombinasi keduanya terhadap pertumbuhan tanaman anggrek Dendrobium sylvanum Rchb. f. pada fase aklimatisasi. Rancangan yang digunakan adalah faktorial 6x4. Faktor pertama yaitu variasi media tanam yaitu media arang, sabut kelapa, ampas tebu, arang kombinasi sabut kelapa, arang kombinasi ampas tebu dan ampas tebu kombinasi sabut kelapa. Faktor kedua waktu pemupukan adalah tanpa pemupukan, 1×7 hari pemupukan, 1 1 14 hari pemupukan dan 1×20 hari pemupukan selama 3 bulan. Hasil penelitian menunjukan ada beda pada variasi media dan waktu pemupukan terhadap pertambahan pertumbuhan panjang dan lebar daun, diameter batang dan panjang akar tanaman anggrek Dendrobium pada fase aklimatisasi. Data yang didapat dianalisis secara statistik menggunakan MANOVA dua arah $(\alpha=5 \%)$ dan tes Duncan. Hasil pada perlakuan media terbaik ditunjukkan oleh perlakuan media ampas tebu kombinasi sabut kelapa. Perlakuan pemupukan terbaik adalah perlakuan pemupukan 1x14 hari, sedangkan untuk interaksi antara media dengan pemupukan hasil terbaik adalah media ampas tebu kombinasi sabut kelapa dengan perlakuan pemupukan 1x14 hari.

Kata Kunci: Media tanam, Pemupukan, Pertumbuhan, Dendrobium

\section{INTRODUCTION}

Orchid is the most attractive ornamental plant because it has a variety of shapes and colours, distinctive flavour, and it is quite durable in room condition. Nowadays, orchids often used as decorative flowers and potted plants that have become a flower industry in the world (Mirani et al., 2017). One of Orchid species that has top selling price This requires appropriate strategy on the distribution of fertilizer concentration to give real effect on its growth rate. Fertilizer is used to increase the growth of potted Dendrobium because it contains nutrients needed for orchids.

Orchid plant propagation is conducted using in and quite popular is Dendrobium sylvanum Rchb. $f$ (Iswanto, 2001).

vitro tissue culture. Tissue culture has several stages such as acclimatization phase in which in vitro plantlets adjust from heterotrophic environment to

Orchid can't uptake nutrient significantly from root so foliar nutrient application is very widespread practice in orchid cultivation (Monda et al., vitro propagation. Acclimatization phase is a criti2014). Dendrobium orchid has very low growth rate. cal period in orchid micro-propagation, because 
there are high percentages of damaged and lost plants whenever they are transferred to ex vitro condition (Deb and Imchen 2010). In vitro plantlets are very sensitive to evapotranspiration. Mold and bacteria attack, as well as excessive light intensity, can affect the vegetative growth. Vegetative growth of Dendrobium orchid during acclimatization influenced by environmental conditions such as light, temperature, humidity, and other factors such as the range of media and fertilization intensity.

Appropriate media selection with low septicity, high aeration, suitable permeability, and acidity level are required to ensure initial and autotrophic growth condition. The media is also required to maintain a long-term condition with no reduction in quality to avoid compaction and lack of aeration and permeability (Diaz et al., 2010). The substrate is a solid and porous material, synthetic or natural, combined or uncombined, which allows plants to grow well under controlled environmental conditions (Abad, 1989).

This study aimed to get the optimum growing media and the suitable fertilization time for the growth of Dendrobium sylvanum Rchb. f. on acclimatization phase.

\section{MATERIALS AND METHODS}

\section{Experimental Design}

This experiment was conducted from February until May 2016 in Green House of DD'Orchid Nursery, Areng-Areng Village, Batu, East Java, Indonesia. Materials used in this study were orchid plantlets, which has been obtained from the cultivation of orchid propagation in DD'Orchid Nursery (all of them were using plantlets which had the same number of leaf); pieces of shell charcoal (approximately $2 \mathrm{~cm}$ ), coconut husk, mineral water, bagasse from sugar factory in Kediri, and 2 $\mathrm{g} / \mathrm{L}$ of Gandasil fertilizer (volume of spraying $=10$ $\mathrm{mL}$ per plant).
The experiment was laid out in Factorial Design with $6 \times 4$ treatments was replicated three times. The first factor was growing media which consisted of six media i.e. charcoal media (M), coconut husk media (M2), bagasse (M3), combination of charcoal and coconut husk (M4), combination of charcoal and bagasse (M5), and combination of bagasse and coconut husk (M6), and the second factor consisted of four fertilizer treatments, i.e., without fertilization (P0), 1x7 days fertilization (P1), 1x14 days fertilization (P2) and $1 \times 20$ days fertilization (P3) for 3 months.

\section{Preparation and planting}

A month before planting period, bottles filled with orchid seeds were transferred from DD Orchid Nursery to the greenhouse. They were removed from the bottles using a hook and put into a basin filled with sterile water to separate and remove the media from their roots. After that, they were drained onto dry newspaper. After being dried, 72 seeds were selected that had two homogeneous features. The seeds were grown individually into a single pot sized $5 \mathrm{~cm}$ wide and $6 \mathrm{~cm}$ high with growing media according to the treatments. Treatment media were put into each pot as much as $1 / 3$ part of the bottom of the pot.

\section{Cultivation}

Orchid plants needed to be watered once a day in the morning at $6-7 \mathrm{a} . \mathrm{m}$. using a sprayer to moist growing media. $2 \mathrm{~g} / \mathrm{L}$ of Gandasil was used as fertilizer. The technique was to apply fertilizer directly to the leaves using spray with suitable fertilization time according to the treatments.

\section{Data retrieval}

Data taken from the growth of stem diameter $(\mathrm{cm})$, leaves length and width $(\mathrm{cm})$ and root length $(\mathrm{cm})$. Measurements were made after three month- 
planting. The number of leaves was calculated from the leaves at the bottom to the top of the stem.

\section{Data analysis}

The data normality was tested using Kolmogorov Smirnov test and homogeneity was tested using the Levene test. Furthermore, the data were analysed using two-way MANOVA with a significance level of 0.05. If the data were significantly different, then analysis will be continued using Duncan DMRT test to compare each treatment.

\section{RESULTS AND DISCUSSION}

Statistical analysis showed the difference of Dendrobium plant growth on several media as well as the effect of fertilization time. The plant growth can be seen in several media and treatments using variation of fertilization time (there is include the size of stem diameter, leaf length, leaf width, and root length).

\section{Effect of growing media on orchid growth}

Table 1 showed that charcoal media produced the lowest root length, leaf width, leaf length, and stem diameter among to others. On the contrary, combination media of bagasse and coconut husk increased the size of root length, leaf width, leaf length, and stem diameter. The increase in stem diameter was $0.19 \pm 0.07 \mathrm{~cm}$, different from other growing media treatment. This is due to the charcoal media has a hard texture which made it could not penetrate for the roots. Thus, orchid growth was obstructed and couldn't stand in an upright position, charcoal media also has poor nutrients (Supari, 1999).

Coconut husk media was good enough to influence root length growth, in which the root length was longer than that of bagasse media or media using a combination of charcoal and bagasse. However, the size was still lower than treatment using
Table 1. The effect of growing media on orchid growth (Dendrobium sp.)

\begin{tabular}{lcccc}
\hline \multirow{2}{*}{$\begin{array}{l}\text { Treatments of } \\
\text { growing media }\end{array}$} & $\begin{array}{c}\text { Stem } \\
\text { diameter }\end{array}$ & $\begin{array}{c}\text { Leaf } \\
\text { length }\end{array}$ & $\begin{array}{c}\text { Leaf } \\
\text { width }\end{array}$ & $\begin{array}{c}\text { Root } \\
\text { length }\end{array}$ \\
\cline { 2 - 5 } M1 (charcoal) & $0.19 \pm 0.17 \mathrm{a}$ & $0.25 \pm 0.07 \mathrm{a}$ & $0.05 \pm 0.03 \mathrm{a}$ & $0.39 \pm 0.17 \mathrm{a}$ \\
$\mathrm{M} 2$ (coconut husk) & $0.32 \pm 0.11 \mathrm{e}$ & $0.31 \pm 0.13 \mathrm{~b}$ & $0.13 \pm 0.07 \mathrm{c}$ & $1.58 \pm 1.06 \mathrm{e}$ \\
$\mathrm{M} 3$ (bagasse) & $0.30 \pm 0.11 \mathrm{~d}$ & $0.31 \pm 0.12 \mathrm{~b}$ & $0.13 \pm 0.03 \mathrm{c}$ & $1.48 \pm 1.16 \mathrm{~d}$ \\
$\mathrm{M} 4$ (charcoal + & $0.22 \pm 0.09 \mathrm{~b}$ & $0.27 \pm 0.09 \mathrm{a}$ & $0.11 \pm 0.05 \mathrm{~b}$ & $0.85 \pm 0.43 \mathrm{c}$ \\
coconut husk) & & & & \\
M5 (charcoal + & $0.23 \pm 0.04 \mathrm{c}$ & $0.30 \pm 0.14 \mathrm{~b}$ & $0.13 \pm 0.04 \mathrm{c}$ & $0.67 \pm 0.44 \mathrm{~b}$ \\
bagasse) & & & & \\
$\begin{array}{l}\text { M6 (bagasse }+ \\
\text { coconut husk) }\end{array}$ & $0.33 \pm 0.10 \mathrm{e}$ & $0.39 \pm 0.16 \mathrm{c}$ & $0.19 \pm 0.11 \mathrm{~d}$ & $1.84 \pm 1.13 \mathrm{f}$ \\
\hline
\end{tabular}

Note: The numbers marked with the same letters in each column show no significant difference. Meanwhile, the different letters show significant difference according to Duncan Multiple Range Test at the real level of 5\%.

media combination of bagasse and coconut husk (Table 1), whereas the size of stem diameter was bigger than that of charcoal media, bagasse media or combination of charcoal and bagasse media with average value $0.32 \pm 0.11 \mathrm{~cm}$. The value was not significantly different from a combination of coconut husk and bagasse media. While the increase in leaf length in media coconut husk + bagasse was higher than using in media charcoal media. But it was not significantly different from the increase of leaf length in bagasse media or combination of charcoal media with bagasse. The increase in leaf width was higher and significantly different from charcoal media. This was caused by the capacity of water storage of coconut husk was very good, and it contained essential elements such as N, P, K compared to charcoal media (Toharisman, 1991).

Treatment using a combination of charcoal and coconut husk media on root growth was higher than that of charcoal media. However, the growth of stem diameter was lower than that of the fibrous husk coconut media and combination of charcoal and coconut husk media, the value was $0.22 \pm$ $0.09 \mathrm{~cm}$, whereas the growth of leaf length was not significantly different from that of charcoal media (Table 1). The growth of leaf width was significantly different from charcoal media and others, $0.11 \pm$ 
Table 2. Effect of fertilization time on Dendrobium sp. growth

\begin{tabular}{lcccc}
\hline \multirow{2}{*}{$\begin{array}{c}\text { Treatments } \\
\text { of growing } \\
\text { media }\end{array}$} & \multicolumn{4}{c}{ Growth $(\mathrm{cm})$} \\
\cline { 2 - 5 } & Stem diameter & Leaf length & Leaf width & Root length \\
\hline $\begin{array}{l}\text { P0 (without } \\
\text { fertilization) }\end{array}$ & $0.17 \pm 0.04 \mathrm{a}$ & $0.17 \pm 0.05 \mathrm{a}$ & $0.07 \pm 0.03 \mathrm{a}$ & $0.24 \pm 0.07 \mathrm{a}$ \\
$\begin{array}{l}\text { P1 (1x7 day- } \\
\text { fertilization) }\end{array}$ & $0.25 \pm 0.06 \mathrm{~b}$ & $0.30 \pm 0.04 \mathrm{~b}$ & $0.12 \pm 0.05 \mathrm{~b}$ & $1.12 \pm 0.49 \mathrm{~b}$ \\
$\begin{array}{l}\text { P2 (1x14 day- } \\
\text { fertilization) }\end{array}$ & $0.40 \pm 0.09 \mathrm{c}$ & $0.46 \pm 0.10 \mathrm{c}$ & $0.19 \pm 0.09 \mathrm{c}$ & $2.18 \pm 0.09 \mathrm{c}$ \\
$\begin{array}{l}\text { P3 (1x20 day- } \\
\text { fertilization) }\end{array}$ & $0.24 \pm 0.05 \mathrm{~b}$ & $0.29 \pm 0.06 \mathrm{~b}$ & $0.13 \pm 0.05 \mathrm{~b}$ & $0.99 \pm 0.50 \mathrm{~b}$ \\
\hline
\end{tabular}

Note: The numbers marked with the same letters in each column show no significant difference. Meanwhile, the different letters show significant difference according to Duncan Multiple Range Test at the real level of 5\%.

$0.05 \mathrm{~cm}$. Media using a mixing of charcoal and coconut husk had advantages and disadvantages such as low water storage capacity on charcoal media and low nutrients in coconut husk (Ismail, 1987). From Suradinata et al. (2012) study showed that treatment using a combination of coconut husk and charcoal (1: 1) with 2L-1 Gavaota fertilizer has the best growth.

Combination of coconut husk and bagasse media showed the optimal growth (stem diameter, leaf length, leaf width, and root length) and was significantly different from other growing media. This media combination has met the criteria of growing media needed for orchid plants to grow optimal because this media had good aeration and drainage. Thus, the water storage was very good and rich in nutrients (Novian, 2002). Factors that affected plant growth were water, light as well as air temperature and optimal air humidity, if all of those factors were met then plant growth will accelerate through cell division and elongation (Sitompul \& Guritno, 1995).

\section{Effect of fertilization on orchid growth}

Effect of fertilization on acclimatization of orchid in different growing media showed on Table 2. The fertilizer used in these treatments was Gandasil which contains $\mathrm{N}$ nutrient (20\%), P (15\%), $\mathrm{K}(15 \%)$ and additional micro elements $\mathrm{Mg}, \mathrm{Mn}$,
B, Cu, Co, and Zn (Iswanto, 2002). Plant-feeding was done in the morning because orchids belong to the CAM group (Crassulacean Acid Metabolism), the stomata open at night and close during the day. CAM uses the mechanism to bind carbon dioxide at night when stomata open, at the same time water and nutrients also enter exceed stomata. Thus, CAM plants can photosynthesize without losing a large amount of water due to stomatal transpiration (Salisbury \& Ross, 1992).

Treatment using fertilizer for $1 \times 7$ days showed no significant difference in growth (stem diameter, leaf with and length, and root length) compared to that with $1 \times 20$ day-fertilization time. The optimum growth was shown from treatment P2 which used 1 x 14 day-fertilization. This treatment displayed significant difference to the other three treatments (Table 2). This happened because orchid plants absorbed nutrients in growing media and distributed the nutrients through the leaves. Nutrients were given through the leaves by spraying fertilizer directly through the leaves to allow the leaves to grow and develop (Sutedjo, 1999).

In treatment P2 (1x14 day-fertilization time), there was an increase in root length compared to the other treatments which recorded $2.12 \pm 0.09$ $\mathrm{cm}$ based on the Duncan test. Stem diameter, leaf length, leaf width, were significantly different from treatment P0, P1, and P3. This was caused by the nutrient capacity applied to the plants was quite sufficient therefore photosynthesis process can run well. This affected plant growth. Foliar spray fertilizer which applied periodically and evenly can result better in plant growth rather than being applied in one spot at once (Novian, 2002).

The root growth in P3 (1×20 day-fertilization) was lower than compared to treatment P2 (1x14 day-fertilization) and P1 (1x7 day-fertilization). Duncan test showed the growth only $0.99 \pm 0.50$ $\mathrm{cm}$ as seen in Table 2. Stem diameter, leaf length, 
and width were not significantly different from leaves by spraying or watering them. The fertilizer other treatments. It could be seen in treatment P3 would be absorbed through stomata by diffusion which used 1x20 day-fertilization time. This result and would subsequently enter chloroplast cells might be caused by fewer nutrients available so the through guard cells, mesophyll cells, and bundle growth couldn't be as optimum as in treatment P2 sheath and would play a role in photosynthesis with 1 x14 day-fertilization time. (Salisbury \& Ross, 1992).

The media variation with the intensity of ferEffect of interaction between growing media and fertilization intensity on orchid growth tilization was expected to give maximum growth result on the growth of orchid plants in the ac-

For survival, orchids need more nutrients than those that are provided by growth media. Orchids also need fertilization to apply through the leaves. The fertilizer applied directly through the plant's climatization phase. Duncan test showed that the interaction between media with the highest value of fertilization on root length was significantly different from other treatments. The result of treatment

Table 3. Effect of growing media and fertilization time on Dendrobium sp. growth

\begin{tabular}{|c|c|c|c|c|c|}
\hline \multicolumn{2}{|c|}{ Treatments } & \multicolumn{4}{|c|}{ Growth $(\mathrm{cm})$} \\
\hline Media & Fertilizations & Stem diameter & Leaf length & Leaf width & Root length \\
\hline M1 & Not fertlizer & $0.12 \pm 0.02 a$ & $0.19 \pm 0.01 \mathrm{bcd}$ & $0.03 \pm 0.00 \mathrm{a}$ & $0.17 \pm 0.01 a$ \\
\hline M1 & $1 \times 7$ day & $0.18 \pm 0.03 b c$ & $0.24 \pm 0.04 \mathrm{def}$ & $0.04 \pm 0.01 \mathrm{abc}$ & $0.49 \pm 0.01 f$ \\
\hline M1 & 1 x 14 day & $0.30 \pm 0.02 \mathrm{ghi}$ & $0.36 \pm 0.04 \mathrm{jkl}$ & $0.08 \pm 0.03 \mathrm{bcde}$ & $0.58 \pm 0.01 \mathrm{~h}$ \\
\hline M1 & $1 \times 20$ day & $0.16 \pm 0.01 b$ & $0.23 \pm 0.03 c d e$ & $0.07 \pm 0.01 \mathrm{abcd}$ & $0.31 \pm 0.01 d$ \\
\hline M2 & Not fertilizer & $0.21 \pm 0.02 \mathrm{de}$ & $0.18 \pm 0.01 \mathrm{bcd}$ & $0.03 \pm 0.01 \mathrm{ab}$ & $0.26 \pm 0.01 c$ \\
\hline M2 & $1 \times 7$ day & $0.31 \pm 0.03 \mathrm{hi}$ & $0.28 \pm 0.03$ efghi & $0.16 \pm 0.03 \mathrm{ijk}$ & $1.50 \pm 0.01 q$ \\
\hline M2 & $1 \times 14$ day & $0.49 \pm 0.02 \mathrm{k}$ & $0.51 \pm 0.060$ & $0.21 \pm 0.011$ & $3.10 \pm 0.01 \mathrm{t}$ \\
\hline M2 & $1 \times 20$ day & $0.29 \pm 0.02 \mathrm{~g}$ & $0.26 \pm 0.01$ efg & $0.13 \pm 0.01 \mathrm{ghij}$ & $1.44 \pm 0.01 p$ \\
\hline M3 & Not fertilizer & $0.20 \pm 0.01 \mathrm{cde}$ & $0.17 \pm 0.05 b c$ & $0.10 \pm 0.03 \mathrm{defgh}$ & $0.26 \pm 0.01 c$ \\
\hline M3 & $1 \times 7$ day & $0.26 \pm 0.02 f$ & $0.33 \pm 0.03 \mathrm{hijkl}$ & $0.13 \pm 0.03 \mathrm{ghij}$ & $1.27 \pm 0.01 \mathrm{~m}$ \\
\hline M3 & 1 x 14 day & $0.47 \pm 0.02 k$ & $0.48 \pm 0.04 \mathrm{no}$ & $0.17 \pm 0.01 \mathrm{jkl}$ & $3.29 \pm 0.01 u$ \\
\hline M3 & $1 \times 20$ day & $0.26 \pm 0.01 f$ & $0.28 \pm 0.03$ efghi & $0.13 \pm 0.03 f g h i j$ & $1.09 \pm 0.01 \mathrm{i}$ \\
\hline M4 & Not fertilizer & $0.12 \pm 0.01 a$ & $0.15 \pm 0.03 b$ & $0.08 \pm 0.03 \mathrm{bcde}$ & $0.21 \pm 0.01 b$ \\
\hline M4 & $1 \times 7$ day & $0.19 \pm 0.01 \mathrm{cde}$ & $0.30 \pm 0.03$ fghij & $0.08 \pm 0.04 \mathrm{cdef}$ & $0.92 \pm 0.01 \mathrm{k}$ \\
\hline M4 & $1 \times 14$ day & $0.35 \pm 0.01 j$ & $0.37 \pm 0.04 \mathrm{kl}$ & $0.17 \pm 0.01 \mathrm{jkl}$ & $1.38 \pm 0.020$ \\
\hline M4 & $1 \times 20$ day & $0.21 \pm 0.01 \mathrm{e}$ & $0.27 \pm 0.04 f g h i$ & $0.12 \pm 0.03 f g h i j$ & $0.87 \pm 0.01 j$ \\
\hline M5 & Not fertilizer & $0.19 \pm 0.06 \mathrm{bcd}$ & $0.08 \pm 0.01 a$ & $0.09 \pm 0.01$ defg & $0.16 \pm 0.01 a$ \\
\hline M5 & $1 \times 7$ day & $0.21 \pm 0.01 \mathrm{de}$ & $0.36 \pm 0.01 \mathrm{jkl}$ & $0.13 \pm 0.05 \mathrm{ghij}$ & $0.66 \pm 0.01 \mathrm{i}$ \\
\hline M5 & 1 x 14 day & $0.29 \pm 0.01 \mathrm{gh}$ & $0.43 \pm 0.01 \mathrm{mn}$ & $0.18 \pm 0.01 \mathrm{kl}$ & $1.32 \pm 0.01 n$ \\
\hline M5 & $1 \times 20$ day & $0.24 \pm 0.01 f$ & $0.33 \pm 0.08 \mathrm{ijk} \mid$ & $0.12 \pm 0.02$ efghi & $0.53 \pm 0.02 g$ \\
\hline M6 & Not fertilizer & $0.33 \pm 0.01 \mathrm{de}$ & $0.23 \pm 0.03 \mathrm{cde}$ & $0.08 \pm 0.03 \mathrm{bcde}$ & $0.36 \pm 0.01 \mathrm{e}$ \\
\hline M6 & $1 \times 7$ day & $0.48 \pm 0.01 \mathrm{i}$ & $0.32 \pm 0.01 \mathrm{ghijkl}$ & $0.14 \pm 0.01 \mathrm{hijk}$ & $1.87 \pm 0.01 \mathrm{~s}$ \\
\hline M6 & $1 \times 14$ day & $0.48 \pm 0.01 \mathrm{k}$ & $0.63 \pm 0.03 p$ & $0.35 \pm 0.03 \mathrm{~m}$ & $3.42 \pm 0.01 \mathrm{v}$ \\
\hline M6 & $1 \times 20$ day & $0.30 \pm 0.01 \mathrm{ghi}$ & $0.38 \pm 0.01 \mathrm{~lm}$ & $0.21 \pm 0.01 \mathrm{i}$ & $1.73 \pm 0.01 r$ \\
\hline
\end{tabular}

Note: The numbers marked with the same letters in each column show no significant difference and the different letters show significant difference according to Duncan Multiple Range Test at the real level of $5 \%$. 
P6*P2 (combination of coconut husk + bagasse media with intensity $1 \times 14$ day-fertilization) showed $3.42 \pm 0.01 \mathrm{~cm}$ which can be seen in Table 3 . Treatment with the highest value of stem diameter showed no a significant difference to treatments $\mathrm{M} 3{ }^{*} \mathrm{P} 2 ; \mathrm{M} 6{ }^{*} \mathrm{P} 2$, and $\mathrm{M} 2{ }^{*} \mathrm{P} 2$. These results can be seen in Table 3. Whereas, treatment with the highest growth value in leaf length and width showed significant difference to other treatments. The highest value in leaf length and width was shown from treatment $\mathrm{M} 6{ }^{*} \mathrm{P} 2$ (combination of coconut husk + bagasse media with the intensity of $1 \times 14$ day-fertilization), the leaf length was $0.63 \pm 0.03$ $\mathrm{cm}$, and leaf width was $0.35 \pm 0.03 \mathrm{~cm}$.

Optimal growth was probably due to the suitability between media structures, spraying intervals, and good fertilization. It was also caused by an environmental condition (humidity and sunlight). According to Gunawan (1998), orchid plants can adapt to any media; the most important thing is adequate watering and fertilization for each species. In the area with a high intensity of rain and humidity, media which can store water is not recommended because the media would always wet and cause decomposition on roots, but the orchid plant could be maintained according to the condition and the surrounding environment.

Treatment M6* P2 (combination of coconut husk and bagasse media with intensity 1 x14 dayfertilization) has optimal growth. The cause of that has been explained on the influence of media and the effect of fertilization intensity. This result was in accordance with Suradinata et al. (2012), which stated that treatment using a combination of coconut husk and charcoal media with 1: 1 ratio and the application of 2L-1 Gaviota fertilizer showed the best effect on plant height, leaf width, and Dendrobium sp. buds at several observations. Combination and interaction of the media, as well as the intensity of fertilization, could accelerate the growth of orchid plants, particularly in acclimatization phase due to the environmental factors such as humidity, light, water, and temperature. Nutrient contents present in the media supported by appropriate fertilization intensity would also accelerate the growth of orchid plants in the acclimatization phase.

This result corresponded to Tisdale et al. (1990) which stated nitrogen is the macronutrient that is needed by plants. Orchid plant could grow well if exposed to the low intensity of sunlight (25-50\% ${ }^{\circ} \mathrm{C}$ ), it prefers a rather dry environment with the best air temperature $21^{\circ} \mathrm{C}-25^{\circ} \mathrm{C}$ during the day and night $18^{\circ} \mathrm{C}-21^{\circ} \mathrm{C}$, humidity $60-80 \%$ and sufficient watering (Toharisman, 1991). This study was conducted during the rainy season, so the expected condition was achieved.

\section{CONCLUSION}

Growing media affect the growth of Dendrobium sylvanum Rchb. f. Treatment using combination media of coconut husk and bagasse was the best media to use for Dendrobium sylvanum Rchb. f. Optimal fertilization on Dendrobium sylvanum Rchb. $f$ was 1 x14 days-fertilization time. The interaction between growing media (coconut husk + bagasse) and $1 \times 14$ days-fertilization time can accelerate the highest growth.

\section{REFERENCES}

Abad, M. (1989). Los sustratos en horticultura ornamental. Revista Agricola Vegetal, 3, 146-152.

Diaz, L.P., Namur, J.J., Bollati, S.A. \& Arche, O.E.A. (2010). Acclimatization of Phalaenopsis and Cattleya obtained by micropropagation, Rev. Colomb. Biotechnol. 12(2), 27-40. http://www.scielo. org.co/pdf/biote/v12n2/v12n2a03.pdf

Deb, C.R. \& Imchen, T. (2010). An efficient In vitro hardening technique of tissue culture raised plants. Biotechnology, 1-5

Gunawan, L, W., 1998. Budidaya Anggrek. Penerbit Swadaya, Jakarta.

Ismail, I. 1987. Peranan bioearth terhadap status hara makro, sifat-sifat tanah, pertumbuhan, dan bobot kering tanaman tebu pada berbagai ketebalan lapisan tanah atas. Buletin Agronomi 2(2): 7-8. 
Iswanto, H. 2001. Petunjuk Perawatan Anggrek. Jakarta: Agro Media Pustaka.

Iswanto, H. 2002. Petunjuk Perawatan Anggrek. Jakarta: Agro Media Pustaka.

Mirani, A.A., Abul-Soad, A.A. \& Markhand, G.S. (2017). Effect of different substrates on survival and growth of transplanted orchids (Dendrobium nobile cv.) into net house. International Journal of Horticulture and Floriculture, 5(4), 310-317.

Monda, T., Dash, P.K., Ahmed, M., Islam, Md. M. and Ali, Md. H. (2014). Growth performance of orchid (Dendrobium sp.) as influenced by different NPK spray concentration. International Journal of Biosciences, 4(7), 15-27.

Novian, 2002. Petunjuk Pemupukan yang Efektif. Agro Media pustaka, Jakarta.
Salisburry, F.B., dan Ross C.W., 1992. Fisiologi tumbuhan terjemahan jilid 2, Biokimia Tumbuhan. Bandung: ITB.

Supari, DH. 1999. Tuntunan Membangun Agribisnis. PT. Alex Media Komputindo. Sutedjo, M.M. 1999. Pupuk dan Cara Pemupukan. Jakarta: Rineka Cipta.

Tisdale, S.L., E.L. Nelson, and J.D. Beaton. 1990. Soil Fertility and Fertilizer. Fourth edition. New York: Mc Millan Pub. Co.

Toharisman, A. 1991. Potensi Dan Pemanfaatan Limbah Industri Gula Sebagai Sumber Bahan Organik Tanah.

Suradinata, Y.R., Nuraini, A. \& Setiadi, A. (2012). Effect of plant media and concentrations of foliar fertilization on growth of orchids Dendrobium sp. On acclimatization. J. Agrivigor, 11(2), 104- 116. Sitompul, S.M.\& Guritno, B. (1995). Analisis pertumbuhan tanaman, Gadjah Mada University Press, Yogyakarta. 